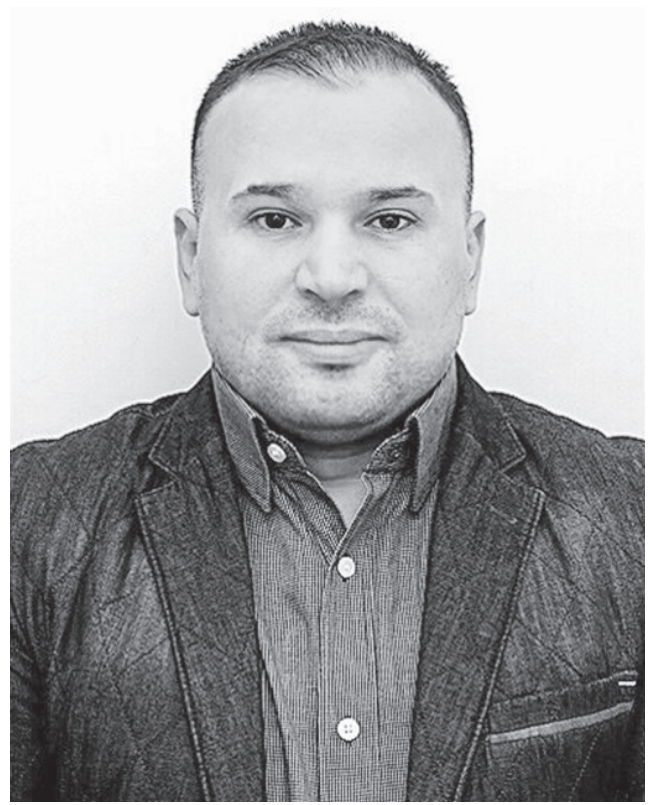

\section{УДК: 351}

https://doi.org/10.32689/2617-2224-

2020-3(23)-178-185

Хассун Мухамед Абдель Маджет, аспірант кафедри публічного адмініструування, Міжрегіональна Академія управління персоналом, 02000, м. Київ, вул. Фрометівська, 2, тел.: 044490 9505, e-mail: hassunmuhamed@ukr.net, https// orcid.org/0000-0003-2103-5651

Хассун Мухаммед Абдель Маджет, аспирант кафедры публичного администрирования, Межрегиональная Академия управления персоналом, 02000, 2. Киев, ул. Фрометовская, 2, тел.: 0444909505 , e-mail: hassunmuhamed@ukr.net, https// orcid.org/0000-0003-2103-5651

Hassun Muhamed Abdel Majid, Postgraduate Student, Department of Public Administration, Interregional Academy of Personnel Management, 02000, Kyiv, Frometivska Str., 2, tel.: 044490 9505, e-mail: hassunmuhamed@ukr.net,https//orcid.org/0000-0003-2103-5651

\title{
ЕВОЛЮЦІЯ СТАНОВЛЕННЯ МЕХАНІЗМІВ ДЕРЖАВНОГО РЕГУЛЮВАННЯ ДИПЛОМАТИЧНОЮ ПОЛІТИКОЮ
}

Анотація. Здійснено аналіз еволюційних процесів становлення механізмів державного регулювання дипломатичною політикою. Обгрунтовано, що у зовнішніх відносинах між країнами однією із найстаріших та найважливіших управлінських інституцій політичної діяльності є інституція регулювання дипломатичних відносин. 3 появою міждержавних зносин стародавнього світу як мирних, так і воєнних, політичні діячі античних Єгипту, Індії, Греції, Риму, Китаю та інших країн розвивали напрями вдосконалення державної політики у сфері дипломатичної діяльності. Розглядаючи державність Стародавньої Індії, у контексті розвитку механізмів публічного адміністрування галуззю дипломатичних відносин зазначено, що використання у практиці міжнародної політики дипломатичних привілеїв та імунітетів є одним з найдавніших і загальновизнаних способів регулювання цієї діяльності у міжнародному праві.

Доведено, що проблематика пошуку балансу в напрямі закономірностей розвитку механізмів публічного адміністрування у галузі дипломатичної ді- 
яльності порушувалась у Стародавньому Китаї раніше, ніж у європейських державах. Мистецтво дипломатичних відносин, як провідного інструментарію впровадження зовнішньополітичної стратегії, є важливим елементом політичної культури громади та невід'ємним інструментом безпеки державних інтересів. Констатовано, той факт, що сучасні історики та державні управлінці доводять, що у Давній Греції існували певні закономірності, які полягали в наявності доволі розвиненої і потужної системи регулювання зовнішньополітичної діяльності та, зокрема, дипломатичних відносин.

Зазначено, що в дипломатичній діяльності Стародавньої Індії заслуговують особливої уваги Закони Ману, які сягають 1 тисячоліття до нашої ери. Згідно з цими нормативно-правовими актами галузі дипломатичних відносин, уникнення військових дій та укладення миру залежали від мистецтва ведення переговорів дипломатичних послів. Відзначено, що принцип недоторканості представників дипломатичних відносин віддзеркалений і в цій державі.

Ключові слова: механізми державного управління, регулювання дипломатичних відносин, Стародавня Індія, зовнішньополітична діяльність, договір Рамзеса-Хаттушиля.

\section{ЭВОЛЮЦИЯ СТАНОВЛЕНИЯ МЕХАНИЗМОВ ГОСУДАРСТВЕННОГО РЕГУЛИРОВАНИЯ ДИПЛОМАТИЧЕСКОЙ ПОЛИТИКОЙ}

Аннотация. Осуществлен анализ эволюционных процессов становления механизмов государственного регулирования дипломатической политикой. Обосновано, что во внешних отношениях между странами одним из старейших и важнейших управленческих институтов политической деятельности есть организация регулирования дипломатических отношений. С появлением межгосударственных отношений древнего мира как мирных, так и военных, политические деятели античных Египта, Индии, Греции, Рима, Китая и других стран развивали направления совершенствования государственной политики в сфере дипломатической деятельности. Рассматривая государственность Древней Индии, в контексте развития механизмов публичного администрирования отраслью дипломатических отношений указано, что использование в практике международной политики дипломатических привилегий и иммунитетов есть одним из древнейших и общепризнанных способов регулирования этой деятельности в международном праве.

Доказано, что проблематика поиска баланса в направлении закономерностей развития механизмов публичного администрирования в области дипломатической деятельности поднималась в Древнем Китае раньше, чем в европейских государствах. Искусство дипломатических отношений, как ведущего инструментария внедрения внешнеполитической стратегии, есть важным элементом политической культуры общества и неотъемлемым инструментом безопасности государственных интересов. Констатировано, тот факт, что современные историки и государственные управленцы доказывают, что в Древней Греции существовали определенные закономерности, 
которые заключались в наличии достаточно развитой и мощной системы регулирования внешнеполитической деятельности и, в частности, дипломатических отношений.

Отмечено, что в дипломатической деятельности Древней Индии заслуживают особого внимания Законы Ману, которые относятся к 1 тысячелетию до нашей эры. Согласно этим нормативно-правовым актам области дипломатических отношений, избежание военных действий и заключение мира зависели от искусства ведения переговоров дипломатических послов. Отмечено, что принцип неприкосновенности представителей дипломатических отношений отражен и в этом государстве.

Ключевые слова: механизмы государственного управления, регулирования дипломатических отношений, Древняя Индия, внешнеполитическая деятельность, договор Рамсеса-Хаттушиля.

\section{EVOLUTION OF FORMATION OF THE MECHANISMS OF STATE REGULATION THROUGH DIPLOMATIC POLICY}

Abstract. The article analyzes the evolutionary processes of the formation of mechanisms of the state regulation through diplomatic policy. It is justified that in the external relations between the countries one of the oldest and most important administrative institutions of the political activity is the institution of regulation of diplomatic relations. With the advent of the interstate relations of the ancient world, both peaceful and military, the political figures of ancient Egypt, India, Greece, Rome, China and other countries have developed directions for improving the public policy in the field of diplomatic activity. Considering the statehood of Ancient India, in the context of the development of mechanisms of the public administration in the field of diplomatic relations, it has been stated that the use in diplomatic policy of the diplomatic privileges and immunities is one of the most ancient and widely recognized ways of regulating this activity in the international law.

It has been proved that the problem of finding a balance in the direction of the patterns of development of mechanisms of the public administration in the field of diplomatic activity was raised earlier in the ancient China than in the European countries. The art of diplomatic relations, as a leading tool for the implementation of a foreign policy strategy is an important element of the political culture of the community and an indispensable tool for the security of the state interests. It is ascertained by the fact that modern historians and government officials argue that there were certain patterns in Ancient Greece that consisted of a sufficiently developed and powerful system of regulation of the foreign policy and, in particular, of the diplomatic relations.

It is noted that the diplomatic activities of Ancient India deserve special attention by the Laws of Manu dating back to the $1^{\text {st }}$ millennium BC. According to these regulations of the diplomatic relations, the avoidance of hostilities and the conclusion of peace depended on the art of negotiating of the diplomatic ambas- 
sadors. It is noted that the principle of inviolability of the representatives of diplomatic relations is also reflected in this country.

Keywords: mechanisms of the public administration, regulation of the diplomatic relations, Ancient India, foreign policy activity, Ramses-Hattushil treaty.

Постановка проблеми. В сучасних умовах широкомасштабної глобалізації у різноманітних галузях діяльності та інституціях держав, виникають видозмінені загрози міжнародній, національній безпеках та громадському устрою. Саме тому, враховуючи накопичений досвід, всебічний розвиток механізмів державного регулювання дипломатичними відносинами ставиться на перший план у світовій практиці XXI ст.

Країни, як основні суб'єкти зовнішніх відносин, саме за допомогою дипломатичних механізмів ведення своєї політичної діяльності реалізують найважливіші прагнення та наміри у напрямах забезпечення державних громадсько-правових та суспільних інтересів [1, с. 6]. Досвід впровадження нових механізмів державного регулювання дипломатичною політикою доводить, що розвиток процесів удосконалення національного управління нею у будь-якій країні потрібно досліджувати та розвивати, вважаючи його одним із стратегічних напрямів збільшення результативності діяльності на міжнародному, державному та регіональному рівнях.

Варто зазначити, що в усьому світі, після утворення державності, міжнародні відносини, а, в тому числі, і дипломатичні, виходять на новий рівень розвитку та набувають нових конфігурацій. Саме тому, осо- бливого значення набуває питання дослідження історичних процесів становлення та розвитку механізмів державного регулювання у сфері дипломатичних відносин, а, також, приділення уваги дослідженню та опрацюванню теоретичних засад, методів, конфігурацій, механізмів та інструментарію міждержавного управління політичною діяльністю між державами, а, також, регулювання реалізації діяльності інституцій, які займаються посольською діяльністю та веденням переговорів між державами, виявленням способів владнання конфліктних питань та укладання союзів між ними [2, с. 8].

Отже, беручи до уваги тенденції розвитку цього напряму, маємо констатувати, що актуальним буде не тільки хронологічне дослідження процесів становлення та розвитку механізмів державного регулювання у сфері дипломатичних відносин держав та відповідний інструментарій забезпечення їх реалізації, а й дослідження трансформацій дипломатичних відносин та державної політики управління ними, як історичного та політичного феномену, аналізування функцій державного управління дипломатичними відносинами, розкриття критеріїв результативності цих відносин [3].

Аналіз останніх досліджень та публікацій. Велика кількість досліджень як вітчизняних, так і зарубіж- 
них вчених, практиків присвячена питанням дипломатичних відносин та державної політики управління ними. Так, актуальні проблеми створення дипломатичної теорії та практики досліджували у свої працях: В. І. Головченко [7], Є. П. Гончар [1], А. Л. Зінченко [2], О. С. Конопляник [4], Т. М. Лященко [6], О. П. Сагайдак [8], В. Г. Ціватий [3], Ю. С. Шемшученко [5].

Мета статті. Метою статті є визначення природи становлення механізмів державного регулювання дипломатичною політикою.

Виклад основного матеріалу. Icторичні джерельні бази у сфері державного регулювання дипломатичних відносин містять факти про те, що у стародавньому світі лідери громад використовували дипломатію та методи дипломатичних перемовин для врегулювання конфліктів та розв’язання воєнних ситуацій. Для забезпечення захисту посередників дипломатичних відносин було впроваджено принцип особистої недоторканості у ході переговорного процесу. Цей принцип став найважливішим у дипломатичному праві сьогодення.

3 огляду на зазначене, можна сказати, що у зовнішніх відносинах між країнами однією із найстаріших та найважливіших управлінських інституцій політичної діяльності є інституція регулювання дипломатичних відносин. 3 появою міждержавних зносин стародавнього світу, як мирних, так і воєнних, політичні діячі античних Єгипту, Індії, Греції, Риму, Китаю та інших країн розвивали напрями вдосконалення державної політики у сфері дипломатичної діяльності.
Однією з перших відомих, на сьогоднішній день, у теоретично-філософському контексті спроб дослідити проблематику публічного управління дипломатичними відносинами стало підписання договору між фараоном Рамзеса II та царем хетів Хаттушилем III у Стародавньому Єгипті 1296 року до нашої ери. Цей античний нормативно-правовий акт дипломатичної галузі складався з таких частин:

- преамбула;

- статті;

- гарантії щодо виконання умов договору - клятви у дотриманні прийнятих обов'язків та покарання у разі недотримання умов договору.

Договір Рамзеса-Хаттушиля був одним із показових у критеріальному значенні характеристик державного устрою країн стародавнього світу. Значення поняття “держава” прирівнювалось до особистості вождя як представника верховної влади. Тому, необхідно зазначити, що, згідно з цією концепцією, всі дипломатичні перемовини велися тільки від імені володара держави, що означало цілковите гарантування безпеки та недоторканості всіх суб'єктів дипломатичних відносин: послів, переговорників, вісників [4, с. 25].

Хочемо, також, зазначити, що активна зовнішня політика держав Стародавнього Сходу зумовила відкладення значної джерельної бази.

Еволюція змістовного наповнення поняття “дипломатичні відносини”, яке є складовою еволюції дослідження державного регулювання у контексті міжнародного співробітництва, віддзеркалена у нормативно-правових актах щодо зов- 
нішньої експансії Стародавнього Єгипту.

Одним із таких документів було Телль-Амарнське (Телль-ельАмарнське) листування 1887-1888 років до нашої ери, яке відображало дипломатичну діяльність Аменхотепа IV (Ехнатона) та його батька Аменхотепа III. Велика кількість глиняних табличок з листами до володарів Вавилона, Палестини, Сирії та інших держав зберігалась у відомчому архіві, як в одній з державних інституцій [5, с. 34].

Розглядаючи державність Стародавньої Індії, у контексті розвитку механізмів публічного адміністрування галуззю дипломатичних відносин, зазначу, що використання у практиці міжнародної політики дипломатичних привілеїв та імунітетів є одним з найдавніших і загальновизнаних способів регулювання цієї діяльності у міжнародному праві.

Процес створення дипломатичної теорії та практики нерозривно пов'язаний з проміжком історії розвитку племінного ладу суспільства. За допомогою переговорного процесу вирішувались питання військових відносин та перемир'я між племенами. Деякі позиції перемовин ставали традиційними і такі звичаї стали базою договірних дипломатичних відносин.

У дипломатичній діяльності Стародавньої Індії заслуговують особливої уваги Закони Ману, які сягають I тисячоліття до нашої ери. Згідно 3 цими нормативно-правовими актами галузі дипломатичних відносин, уникнення військових дій та укладення миру залежало від мистецтва ведення переговорів дипломатичних послів. Варто зазначити, що принцип недоторканості представників дипломатичних відносин віддзеркалений і в цій державі [6].

Можна довести, що проблематика пошуку балансу у напрямі закономірностей розвитку механізмів публічного адміністрування у галузі дипломатичної діяльності порушувалась у Стародавньому Китаї раніше, аніж у європейських державах. Мистецтво дипломатичних відносин, як провідного інструментарію впровадження зовнішньополітичної стратегії, є важливим елементом політичної культури громади та невід'ємним інструментом безпеки державних інтересів [7, с. 2].

Системоутворюючі ідеї філософів Стародавнього Китаю займали важливе місце у наукових та політичних дискусіях і присвячувались питанням пошуків оптимального розвитку механізму публічного адміністрування дипломатичних відносин. Із стратегічними завданнями китайської традиційної дипломатії органічно пов'язувались методи її тактичної реалізації, що грунтувалися на, розробленому у V-III ст. до н. е., базовому принципі: “Дружити з далекими варварами проти близьких” [7, с. 7-11].

Маю констатувати той факт, що сучасні історики та державні управлінці доводять, що у Стародавній Греції існували певні закономірності, які полягали у наявності досить розвиненої і потужної системи регулювання зовнішньополітичної діяльності та, зокрема, дипломатичних відносин.

Важливо зазначити, що однією із форм дипломатичних відносин у Греції була гостинність. Розв’язання 
спірних питань, що виникали між громадами, проходило за допомогою спеціально уповноважених осіб (послів). Процес обрання послів був дозволений тільки багатим верствам населення. Важливим аспектом обрання послів була відповідність наступним вимогам: вони повинні бути не молодші 50 років (звідси термін “старійшина”), справляти позитивне враження на слухачів, мати належні ораторські здібності. Послам видавали рекомендаційні листи, які визначали мету і завдання посольства, a, також, давали відповідні інструкції (дві воскові дощечки - diploma). Одним з головних обов'язків послів Греції було укладення союзу з іншими державами і підписання договорів, які супроводжувалися певними формальностями [8].

Висновки. Проведений аналіз державно-правової природи становлення механізмів державного регулювання дипломатичною політикою свідчить про їх складність та суперечливість умов формування. Доведено, що проблематика пошуку балансу у напрямі закономірностей розвитку механізмів публічного адміністрування у галузі дипломатичної діяльності порушувалась у Стародавньому Китаї раніше, аніж у європейських державах.

Визначено, що договір Рамзеса-Хаттушиля був одним із показових у критеріальному значенні характеристик державного устрою країн стародавнього світу. Значення поняття “держава” прирівнювалось до особистості вождя як представника верховної влади. Згідно з цією концепцією, всі дипломатичні перемовини велися тільки від імені воло- дара держави, що означало цілковите гарантування безпеки та недоторканості всіх суб'єктів дипломатичних відносин: послів, переговорників, вісників.

Перспективним напрямом подальших досліджень з даного питання $є$ розвиток розуміння сучасного стану механізмів реалізації державної політики у сфері дипломатичних відносин, що вирізняється базуванням на досвіді розвинених країнах світу.

\section{СПИСОК ВИКОРИСТАНИХ ДЖЕРЕЛ}

1. Гончар C. П. Дипломатія в умовах конфлікту : магістерська дис. : 054 Соціологія / Гончар Свгеній Петрович. Київ, 2018.91 с.

2. Зінченко А. Л. Історія дипломатії : від давнини до нового часу : навч. посіб. для студ. вищ. навч. закл. Вінниця: Нова книга, 2002. 433 с.

3. Ціватий В. Г. Свропейська зовнішня політика, інститути дипломатії та дипломатичний інструментарій доби раннього Нового часу (XVI-XVIII століття) [Електронний ресурс] // Наук. зап. [Вінниц.держ. пед. ун-ту імені Михайла Коцюбинського]. Серія : Історія. 2014. Вип. 22. С. 188. Режим доступу:http://nbuv.gov.ua/ UJRN/Nzvdpu_ist_2014_22_40

4. Конопляник O. С. Адміністративноправове регулювання охорони дипломатичних представництв іноземних держав в Україні : дис. ... канд. юрид. наук: 12.00.07. Київ, 2015. 259 c.

5. Державне управління в країнах Стародавнього Сходу: навч. посіб. / В. В. Омельчук (кер. авт. кол., вступ), [авт. передмови Ю. С. Шемшученко]. Київ. Серія: Світові традиції державного управління. 624 с. 
6. Лященко Т. М. Правовий статус дипломатичних представництв: монографія [Електронний ресурс]. Київ: ПП Баришев К. В. , 2008. 190 с. Режим доступу: http://194.44.152.155/ elib/local/r165.pdf

7. Головченко B. I. Традиційний і модерний Китай: політична культура та дипломатія // Актуальні проблеми міжнародних відносин. Київ, 2014. № 4. Серія: Політичні науки. C. $1-10$.

8. Дипломатичний протокол та етикет: навч. посіб. [Електронний ресурс] / О. П. Сагайдак. Київ: Знання, 2006. 380 c. Режим доступу: http://politics. ellib.org.ua/pages-4128.html

\section{REFERENCES}

1. Gonchar E. P. (2018). Diplomatiya v umovakh konfli`ktu [Diplomacy in Conflict]. Candidate's thesis. Kiev: Kiev [in Ukrainian].

2. Zinchenko A. L. (2002). Istoriya diplomatiyi : vid davnini do novogo chasu [History of diplomacy: from ancient times to modern times]. Vinnitsa: Nova kniga [in Ukrainian].

3. Tsivaty V. G. (2014) Yevropejska zovnishnya politika, instituti diplomatiyi ta diplomatichnij instrumentarij dobi rannogo Novogo chasu (XVI-XVIII stoli'ttya) [European Foreign Policy, Institutions of Diplomacy and the Diplomatic Instrumentation of the Early Modern Times
(XVI-XVIII Centuries)]. Naukovi zapiski Vinniczkogo derzhavnogo pedagogichnogo universitetu imeni Mikhajla Koczyubinskogo - Scientific notes of Vinnytsia State Pedagogical University named after Mikhail Kotsyubynsky, 22, 188 [in Ukrainian].

4. Konoplyanyk O. S. (2015). Administrativno-pravove regulyuvannya okhoroni diplomatichnikh predstavnicztv inozemnikh derzhav $\mathrm{v}$ Ukrayini [Administrative and legal regulation of protection of diplomatic missions of foreign states in Ukraine]. Candidate's thesis. Kiev: Kiev [in Ukrainian].

5. Shemshuchenko Yu. S. Derzhavne upravlinnya v krayinakh Starodavnogo Skhodu [Public administration in the countries of the Ancient East]. Kyiv: Znannia [in Ukrainian].

6. Lyashchenko T. M. (2008). Pravovij status diplomatichnikh predstavnicztv [Legal Status of Diplomatic Missions]. Kyiv: PP Barishev [in Ukrainian].

7. Golovchenko V. I. (2014) Tradiczijnij i modernij Kitaj: politichna kultura ta diplomatiya [Traditional and Modern China: Political Culture and Diplomacy]. Aktualni problemi mizhnarodnikh vidnosin - Current Issues in International Relations, 4, 1-10 [in Ukrainian].

8. Sahaidak O. P. (2006) Diplomatichnij protokol ta etiket [Diplomatic Protocol and Etiquette] Kyiv: Znannia [in Ukrainian]. 